\title{
Cellular stress response in Eca-109 cells inhibits apoptosis during early exposure to isorhamnetin
}

\author{
C. SHI ${ }^{1, \ddagger}$, L. Y. FAN ${ }^{1, \neq}$, Z. CAI ${ }^{1}$, Y. Y. LIU ${ }^{2}$, C. L. YANG ${ }^{1, *}$
}

${ }^{1}$ Key Laboratory of Bio-resources and Eco-environment (Ministry of Education), College of Life Sciences, Sichuan University, Chengdu, Sichuan 610064,PR China; ${ }^{2}$ Key Laboratory of Chronobiology, Ministry of Health (Sichuan University), West China School of Preclinical and Forensic Medicine, Sichuan University, Chengdu, 610041 Sichuan, PR China

${ }^{*}$ Correspondence: $y$ cl108@yahoo.com.cn

${ }^{*}$ Contributed equally to this work.

\section{Received November 23, 2011 / Accepted January 13, 2012}

\begin{abstract}
The flavonol aglycone isorhamnetin shows anti-proliferative activity in a variety of cancer cells. Previous work, from our laboratory showed that isorhamnetin inhibits the proliferation of human esophageal squamous carcinoma Eca-109 cells in vitro, but only after $72 \mathrm{~h}$ of exposure. This led us to propose that isorhamnetin exposure induces a cellular stress response that inhibits the antiproliferative and apoptotic effects of the compound during early exposure. To test this hypothesis, the present study examined the effects of isorhamnetin on Eca-109 cells during the first $72 \mathrm{~h}$ of exposure. Cell growth was assessed using the trypan blue exclusion assay, and expression of I $\kappa \mathrm{B} \alpha, \mathrm{NF}-\kappa \mathrm{B} / \mathrm{p} 65$, NF- $\kappa \mathrm{B} / \mathrm{p} 50$, phospho-Akt, Bcl-2, COX-2, Mcl-1, Bax, p53 and Id- 1 were analyzed by Western blot. During the first $72 \mathrm{~h}$ of exposure, NF- $\mathrm{kB} / \mathrm{p} 65$ and NF- $\mathrm{kB} / \mathrm{p} 50$ accumulated in nuclei and expression of COX-2, Bcl-2 and Mcl-1 increased. In contrast, expression of IкB $\alpha$ and Bax fell initially but later increased. Expression of phospho-Akt and p53 showed no detectable change during the first $48 \mathrm{~h}$. Pretreatment with the NF- $\kappa$ B inhibitor MG132 before exposure to isorhamnetin blocked the nuclear accumulation of p50 and p65, thereby inhibiting cell proliferation. These results show that during early exposure of Eca- 109 cells to isorhamnetin, the NF- $\mathrm{kB}$ signaling pathway is activated and COX-2 expression increases, and this increase in expression partially inhibits isorhamnetin-induced apoptosis. Beyond $72 \mathrm{~h}$ of exposure, however, the apoptotic effect of isorhamnetin dominates, leading to inhibition of the NF- $\kappa B$ pathway and of cellular proliferation. These results will need to be taken into account when exploring the use of isorhamnetin against cancer in vivo.
\end{abstract}

Key words: isorhamnetin, Eca-109, NF- $\kappa B, C O X-2$, cellular stress response

Esophageal cancer belong to highly malignant tumors and it has the sixth highest mortality rate among all known cancers [1]. Despite the numerous risk factors associated with esophageal cancer, all cases can be classified as either esophageal squamous cell carcinoma (ESCC) or adenocarcinoma $[2,3]$. Except traditional therapies, new treatment methods of ESCC are under investigation.

Isorhamnetin is one type of flavonol aglycone from the sea buckthorn (Hippophae rhamnoides L). Isorhamnetin has been found to have numerous effects on cancer cells, including antioxidant activity and growth inhibition [4.5.6]. Our previous work showed that isorhamnetin inhibits the growth of Eca-109 cells from human esophageal squamous carcinoma and induces apoptosis [7]. However, these effects were not observed until after $72 \mathrm{~h}$ of exposure, leading us to suggest that isorhamnetin initially induces a cellular stress response that inhibits its antiproliferative and apoptotic effects.

The NF- $\mathrm{kB}$ signaling pathway has been closely linked to the cellular stress response [8]. The NF- $\kappa B$ family contains five members: p50, p52, p65 (RelA), c-Rel, and RelB, which are encoded, respectively, by the genes NFKB1, NFKB2, RELA, $R E L$, and RELB. Since the $\mathrm{p} 50 / \mathrm{p} 65$ heterodimers are responsible for most NF- $\kappa B$ activity in cells, it is usually referred to as NF- $\kappa B$ [9]. Some reports have shown that activated NF- $\kappa B$ exerts anti-oxidative and anti-apoptotic effects by regulating the gene expression of bcl-2, cytoplasmic Mn-superoxide dismutase, TNF- $\alpha$ and related genes, as well as the release of cytochrome $C[10,11]$. In addition, stimulation of the NF- $\mathrm{kB}$ pathway in LNCaP cells from human prostate adenocarcinoma activates the Inhibitor of differentiation/DNA binding protein- 
1 (Id-1), which appears to promote cell survival in a number of human cancers by upregulating the expression of $\mathrm{Bcl}-\mathrm{xL}$ and ICAM-1 [12]. A number of factors have been shown to activate the NF- $\mathrm{KB}$ pathway, including the serine/threonine kinase Akt, which is in turn activated by numerous growth factors and other factors. In the Jurkat T-cell line, Akt induces expression of transcription factors of the NF-kB family [13]. Whether activation of NF- $\mathrm{kB}$ also involves Akt phosphorylation in isorhamnetin-treated cells remains a question.

Cyclooxygenases play a key role in the biosynthesis of prostaglandins (PGs) from arachidonic acid, and some of these enzymes have been linked to cancer progression and metastasis. Three cyclooxygenase isozymes are known. COX-1 is a constitutively expressed housekeeping gene and appears to be responsible for the production of PGs. It is expressed in most tissues $[14,15]$. In contrast, COX-2 shows basal expression, which in certain tissues rapidly increases in response to pro-inflammatory mediators $[16,17,18,19]$. Meanwhile, a third isoform named COX-3, which is COX-1 splicing variant, was identified one decade ago; it plays a role in fever and pain processes [20]. COX-2 expression has been linked to carcinogenesis, tumor growth promotion, inhibition of apoptosis, angiogenesis and metastasis [21]. Its expression is induced by tumor promoters, growth factors and cytokines [22, 23, 24, 25], and this upregulation appears to occur via downregulation of p53 or activation of the Akt signalling pathway [26, 27, 28]. Isorhamnetin has also been shown to inhibit COX-2 expression, which may help to explain its anticancer effects [29].

In the present study, our aim was focused on the molecular events induced by isorhamnetin in Eca-109 cells within the first $72 \mathrm{~h}$ of exposure, in order to determine whether the cellular stress response causes the observed delay in the antiproliferative and apoptotic effects of the compound. To this end, we monitored the activation state of the NF- $\kappa B$ signaling pathway and COX-2 expression levels during early exposure to the compound.

\section{Material and Methods}

Reagents. Isorhamnetin was purchased from MEDCO Pharmaceutical (Chengdu, China), and cisplatin was purchased from West China Hospital of Sichuan University (Chengdu, China). MG132 was purchased from Calbiochem (Germany) and dissolved in dimethylsulfoxide (DMSO) to a final concentration of $2 \mathrm{mM}$. Antibodies used for Western blotting were purchased from the following manufacturers: anti-p53 (sc-99), anti-Bcl-2 (sc-492), anti-Id-1 (sc-488) and anti-NF- $\mathrm{kB} / \mathrm{p} 65$ (sc-8008) antibodies were from Santa Cruz Biotechnology (USA); anti-COX-2 (ZA0243), anti-Mcl1(ZA0569), anti-IkBa (ZA0509), anti-Akt(T308) (ZP0026) and anti-Akt(S473) (ZP0024) antibodies were from ABZoom (Chengdu, China); and anti- $\beta$-actin, anti-NF- $\mathrm{kB} / \mathrm{p} 50$ and anti-Bax antibodies were from BOSTER (Chengdu, China). Horseradish peroxidase-conjugated secondary antibodies (sc2004) were from Santa Cruz Biotechnology (USA).
Cell Culture and Treatments. The human ESCC line Eca109 was obtained from the Institute of Biochemistry and Cell Biology (Beijing, China). Cells were cultivated in Dulbecco's modified Eagle's medium (DMEM) supplemented with 10\% fetal bovine serum (FBS), penicillin $(100 \mathrm{U} / \mathrm{ml})$ and streptomycin $(100 \mathrm{U} / \mathrm{ml})$. And were maintained in a humidified atmosphere of $5 \% \mathrm{CO}_{2}$ at $37^{\circ} \mathrm{C}$.

Isorhamnetin was dissolved in $0.1 \% \mathrm{NaOH}$, diluted with routine medium, and finally filtered through one $0.22 \mu \mathrm{m}$ microproefilter [7]. Since our previous work showed the $50 \%$ inhibitory concentration (IC50) of isorhamnetin to be $130 \mu \mathrm{M}(40 \mu \mathrm{g} / \mathrm{ml})$ for Eca-109 cells [7], this concentration was used in the present study and served as a treatment group. Eca-109 cells exposed to cisplatin $(30 \mu \mathrm{M})$ served as a positive control for anticancer activity, and cells cultured in DMEM served as a negative control.

In a second experiment, cultures were treated for $90 \mathrm{~min}$ with the NF- $\mathrm{KB}$ inhibitor MG132 $(2 \mu \mathrm{M})$ or $0.1 \%$ DMSO vehicle, these additives were washed out with several changes of fresh DMEM, and then the cultures were incubated with isorhamnetin for $48 \mathrm{~h}$.

Trypan blue exclusion assay. This assay was carried out to determine the viability of Eca-109 cells treated with isorhamnetin. Briefly, equal numbers of Eca- 109 cells $\left(1.0 \times 10^{5}\right)$ were seeded into $6-\mathrm{cm}$ culture dishes and incubated overnight. Then these cells were treated with $130 \mu \mathrm{M}$ isorhamnetin (experimental), $30 \mu \mathrm{M}$ cisplatin (positive control), or left untreated (negative control), and incubated for $24,48,72,96,120 \mathrm{~h}$. Viable cells from all three conditions were counted each day. Growth curves were generated in which each point was the average of three experiments.

Western blotting. Each day, Eca-109 cells from the isorhamnetin-treated group were harvested using trypsin. Cells were lysed in SDS loading buffer [ $125 \mathrm{mM}$ Tris- $\mathrm{HCl}(\mathrm{pH} 7.5), 5 \mathrm{mM}$ EDTA, 1\% (w/v) SDS, $1 \mathrm{mM}$ phenylmethylsulfonyl fluoride], boiled for $5 \mathrm{~min}$ and centrifuged at $12,000 \mathrm{~g}$ for $10 \mathrm{~min}$. Supernatants were collected and used as whole-cell extract. The nuclear protein fraction was obtained using NE-PER nuclear extraction reagents (Bioteke, Beijing, China). Subsequently, protein concentrations were estimated using the BCA Protein Assay Kit (Bioteke). Protein samples (30-50 $\mu \mathrm{g}$ ) were fractionated by polyacrylamide gel electrophoresis (Bio-Rad) and transferred to a nitrocellulose membrane. After blocking with Blotto (5\% non-fat milk) for $1 \mathrm{~h}$ at room temperature, membranes were incubated with one or more of the following primary antibodies overnight at $4{ }^{\circ} \mathrm{C}$ : Bax (1:400), Mcl-1

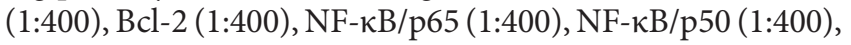
IкBa (1:400), phospho-Akt (1:400), COX-2 (1:500), p53 (1:400), Id-1 (1:400), and $\beta$-actin (1:1000). Then membranes were incubated with horseradish peroxidase-conjugated secondary antibody (1:10000) for $1 \mathrm{~h}$ at room temperature. All antibody dilutions were prepared in Blotto. Immunoblots were visualized by enhanced chemiluminescence (ECL; Tiangen, Beijing, China) and bands were analyzed by densitometry using Quantity One 4.6.2 software (Bio-Rad, San Diego, USA). 


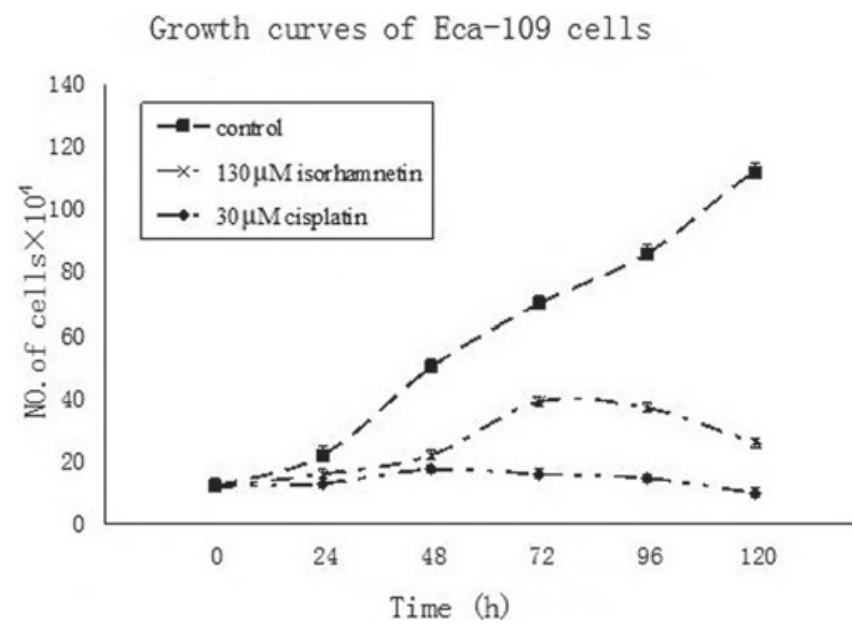

Figure 1. Growth curves of isorhamnetin-treated Eca-109 cells determined by the trypan blue exclusion assay. The number of viable cells treated with $130 \mu \mathrm{M}$ isorhamnetin increased continuously during the first $72 \mathrm{~h}$, in contrast to the cisplatin-treated cultures. However, the number of viable cells decreased significantly during the following $48 \mathrm{~h}$.

Statistical analysis. Data were obtained from at least three independent experiments. The one-way ANOVA test and Student's t test were used to analyze differences, and $\mathrm{p}<$ 0.05 was considered statistically significant. All statistical calculations were carried out using SPSS 16.0 (SPSS, Inc.; Chicago, USA). Eca-109 growth curves were plotted using Excel 2003.

\section{Results}

Isorhamnetin fails to inhibit proliferation of Eca-109 cells completely during early exposure. Eca-109 cells $\left(1.0 \times 10^{5}\right.$ cells/well) were plated into 24 -well dishes. After exposure to $130 \mu \mathrm{M}$ isorhamnetin and $30 \mu \mathrm{M}$ cisplatin for $24,48,72,96$, and $120 \mathrm{~h}$ respectively, cells viability was assessed using the trypan blue exclusion assay. Compared with counterpart of the control group, the number of viable cells from isorhamnetintreated group increased gradually but significantly during the first $72 \mathrm{~h}$, then fell dramatically over the following $48 \mathrm{~h}$; on

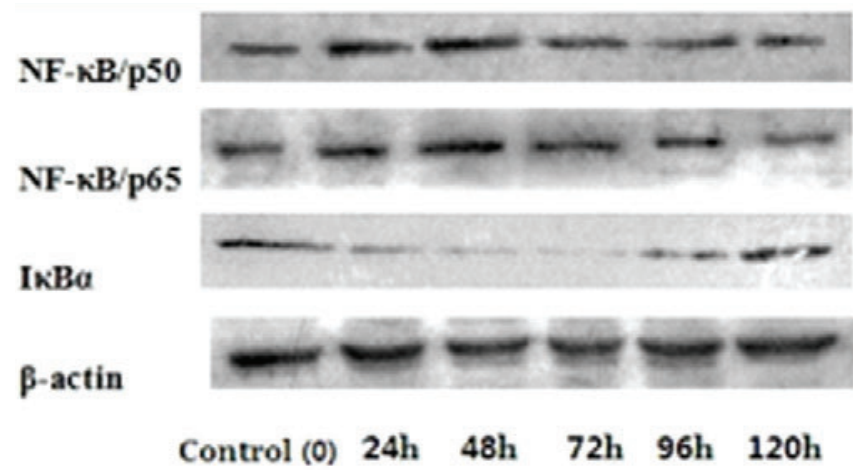

Figure 2. Effect of isorhamnetin on levels of NF- $\mathrm{BB} / \mathrm{p} 50, \mathrm{NF}-\kappa \mathrm{B} / \mathrm{p} 65$ and IкBa in Eca-109 cells. After treatment of cells with $130 \mu \mathrm{M}$ isorhamnetin for $24,48,72,96$ and $120 \mathrm{~h}$, cytoplasmic and nuclear proteins were isolated and analyzed by Western blot. During 0 to $72 \mathrm{~h}$ of treatment, nuclear levels of NF- $\mathrm{NB} / \mathrm{p} 50$ and NF- $\mathrm{NB} / \mathrm{p} 65$ increased dramatically, while the cytoplasmic level of IкB $\alpha$ decreased significantly. However, during 72 to $120 \mathrm{~h}$ of treatment, nuclear levels of NF- $\mathrm{kB} / \mathrm{p} 50$ and NF- $\mathrm{kB} / \mathrm{p} 65$ decreased and the cytoplasmic level of $\mathrm{I} \kappa \mathrm{B} \alpha$ increased. Equal loading was confirmed by stripping the blot and reprobing for $\beta$-actin. Significant changes were determined based on three independent experiments.

${ }^{\star} \mathrm{p}<0.05$ and ${ }^{\star *} \mathrm{p}<0.01$ compared with control $(0 \mathrm{~h}$ of treatment $)$.

the other hand, viable cells in cisplatin group did not increase during $120 \mathrm{~h}$ exposure (Fig. 1).

Exposure to isorhamnetin activates NF- $\mathrm{kB}$ in Eca-109 cells. We then set out to determine whether the ability of Eca109 cells to proliferate after brief exposure to isorhamnetin was associated with activation of cell stress response genes. Western blot analysis of nuclear extracts of isorhamnetin-treated cells showed nuclear accumulation of NF- $\kappa \mathrm{B} / \mathrm{p} 50$ and NF- $\kappa \mathrm{B} / \mathrm{p} 65$ proteins after 24 and $48 \mathrm{~h}$ of exposure. At the same time, the cytoplasmic level of I $\kappa \mathrm{B} a$ decreased, confirming that NF- $\kappa \mathrm{B}$ was activated (Fig. 2, Table 1). Between 48 and $120 \mathrm{~h}$ of exposure, however, when the number of viable cells was decreasing (Fig. 1), cytoplasmic levels of IкBa increased and nuclear levels of NF- $\kappa B / p 50$ and NF- $\kappa B / p 65$ decreased (Fig. 2, Table 1).

Exposure to isorhamnetin induces COX-2 expression in Eca-109 cells. The COX-2 expression pattern of Eca-109 cells during $120 \mathrm{~h}$ exposure to isorhamnetin corresponds to the

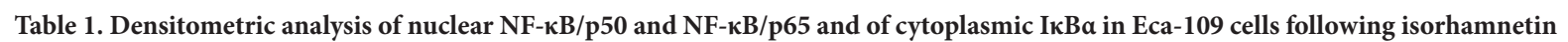

\begin{tabular}{|c|c|c|c|c|}
\hline \multirow[t]{2}{*}{ Time } & \multirow[b]{2}{*}{$\mathrm{N}$} & \multicolumn{3}{|c|}{ Realative Optcal Density } \\
\hline & & $\mathrm{I} \kappa \mathrm{Ba}$ & $\mathrm{NF}-\kappa \mathrm{B} / \mathrm{p} 50$ & $\mathrm{NF}-\kappa \mathrm{B} / \mathrm{p} 65$ \\
\hline 0 & 3 & $5078.33 \pm 227.48$ & $5391.67 \pm 143.30$ & $4886.00 \pm 210.69$ \\
\hline 24 & 3 & $2596.67 \pm 181.62^{\star *}$ & $8668.67 \pm 159.63^{\star *}$ & $6694.67 \pm 237.59^{\star *}$ \\
\hline 48 & 3 & $2059.00 \pm 138.86^{* *}$ & $11190.67 \pm 423.75^{\star \star}$ & $9491.00 \pm 577.43^{\star *}$ \\
\hline 72 & 3 & $1086.33 \pm 68.82^{\star *}$ & $5769.33 \pm 120.08$ & $7961.67 \pm 339.16^{\star *}$ \\
\hline 96 & 3 & $3175.33 \pm 186.80^{* *}$ & $5474.00 \pm 193.03^{*}$ & $5274.67 \pm 198.56^{*}$ \\
\hline 120 & 3 & $4881.00 \pm 279.61^{*}$ & $4681.00 \pm 60.90^{* *}$ & $2789.33 \pm 265.48^{\star *}$ \\
\hline
\end{tabular}

${ }^{*} \mathrm{P}<0.05$ vs. control group ${ }^{* *} \mathrm{P}<0.01$ vs. control group 


\section{CoX-2}

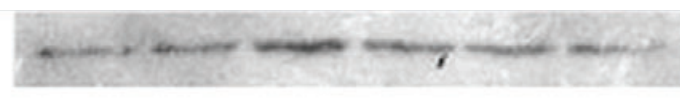

$\beta$-actin

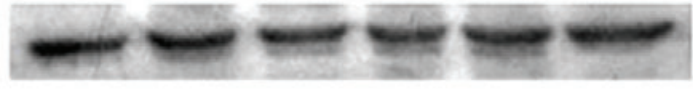

Control (0) $24 \mathrm{~h} \quad 48 \mathrm{~h} \quad 72 \mathrm{~h} \quad 96 \mathrm{~h} \quad 120 \mathrm{~h}$

Figure 3. Effect of isorhamnetin on COX-2 expression in Eca-109 cells. Cells were treated with $130 \mu \mathrm{M}$ isorhamnetin for 24, 48, 72, 96 and $120 \mathrm{~h}$ and whole-cell extracts were analyzed by Western blot. COX-2 expression peaked at $48 \mathrm{~h}$, and it began to decrease sharply at $72 \mathrm{~h}$. Equal loading was confirmed by stripping the blot and reprobing for $\beta$-actin. Significant changes were determined based on three independent experiments.

${ }^{\star} \mathrm{p}<0.05$ and ${ }^{\star *} \mathrm{p}<0.01$ compared with control $(0 \mathrm{~h}$ of treatment $)$.

proliferation trend of these treated cells. COX-2 expression increased during the first $48 \mathrm{~h}$ treatment (Fig. 3, Table 2), which is consistent with the gradually enhanced proliferation during the same period (Fig. 1). Between 72 and $120 \mathrm{~h}$ of exposure, however, COX-2 expression declined (Fig. 3, Table 2), which is in line with the decreased number of viable cells (Fig. 1).
Table 2. Densitometric analysis of COX-2 following isorhamnetin

\begin{tabular}{llc}
\hline $\begin{array}{l}\text { Time } \\
(\mathrm{hr})\end{array}$ & $\mathrm{N}$ & Relative Opitical Density \\
\cline { 3 - 3 } & 3 & $3232.00 \pm 100.26$ \\
24 & 3 & $3791.00 \pm 213.49^{*}$ \\
48 & 3 & $5162.00 \pm 196.07^{* *}$ \\
72 & 3 & $3364.67 \pm 218.28^{*}$ \\
96 & 3 & $2543.67 \pm 147.71^{* *}$ \\
120 & 3 & $2326.33 \pm 124.64^{* *}$ \\
\hline
\end{tabular}

${ }^{\star} \mathrm{P}<0.05$ vs. control group ${ }^{* *} \mathrm{P}<0.01$ vs. control group

Activation of NF-kB and upregulation of COX-2 expression during early exposure of Eca-109 cells to isorhamnetin does not involve Akt phosphorylation. Western blot analysis was used to determine whether phosphorylation of Akt was implicated in the activation of NF- $\mathrm{kB}$. The results show no significant changes in the levels of phospho-Akt (S473) and phospho-Akt (T308) between 0 and $48 \mathrm{~h}$ of isorhamnetin exposure (Fig. 4A, Table 3). These results suggest that Akt was not responsible for NF- $\mathrm{kB}$ activation and peak of COX-2 expression at $48 \mathrm{~h}$.

Table 3. Densitometric analysis of IkBa, COX-2, p-Akt (T308)/(S473) following isorhamnetin

\begin{tabular}{|c|c|c|c|c|c|}
\hline \multirow{2}{*}{$\begin{array}{l}\text { Time } \\
\text { (hr) }\end{array}$} & \multirow{2}{*}{$\mathrm{N}$} & \multicolumn{4}{|c|}{ Relative Optical Density } \\
\hline & & $\mathrm{I} \kappa \mathrm{B} \alpha$ & Cox-2 & p-Akt(T308) & p-Akt(S473) \\
\hline 0 & 3 & $1192.50 \pm 123.62$ & $1227.09 \pm 116.42$ & $1198.84 \pm 116.80$ & $3144.03 \pm 223.89$ \\
\hline 24 & 3 & $927.03 \pm 120.89^{*}$ & $2771.55 \pm 128.62^{*}$ & $1137.49 \pm 121.65$ & $3699.09 \pm 237.52$ \\
\hline 48 & 3 & $383.93 \pm 118.91^{* *}$ & $5439.43 \pm 161.60^{\star *}$ & $1085.58 \pm 121.60$ & $3828.75 \pm 210.72$ \\
\hline
\end{tabular}

${ }^{*} \mathrm{P}<0.05$ vs. control group ${ }^{* *} \mathrm{P}<0.01$ vs. control group

A

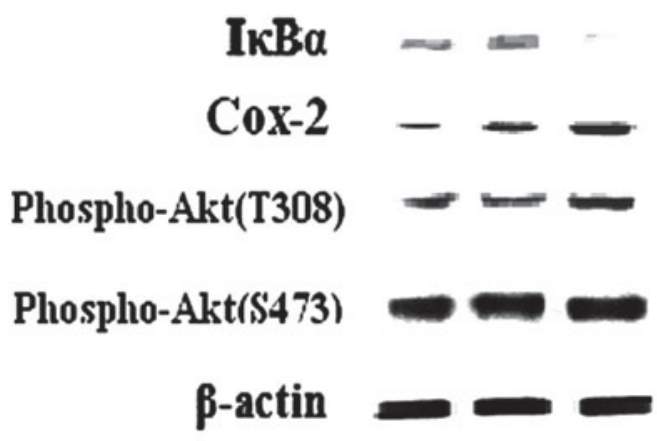

Control 24h $48 \mathrm{~h}$
B

\section{NF- $\mathbf{B} / \mathbf{p} 50$ \\ $\mathrm{NF}-\kappa \mathrm{B} / \mathrm{p} 65$}

Id-1

p53

$\beta$-actin
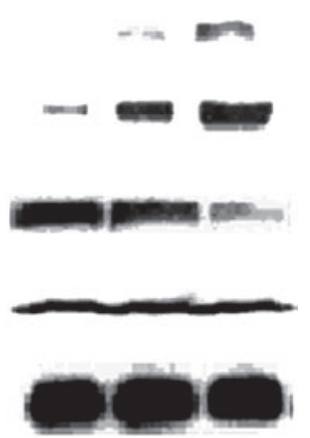

\section{Control 24h 48h}

Figure 4. Relationship among NF-kB, p-Akt, Id-1, p53and COX-2 expression in Eca-109 cells during the first 48 h of exposure to isorhamnetin. Cells were treated with $130 \mu \mathrm{M}$ isorhamnetin for 24 or $48 \mathrm{~h}$ and whole-cell extracts were analyzed by Western blot. (A) Phospho-Akt(T308)/(S473) was not detected under these conditions, whereas the level of NF- $\mathrm{kB}$ peaked at $48 \mathrm{~h}$ and the level of COX-2 increased sharply from 0 to $48 \mathrm{~h}$. (B) The level of Id-1 decreased significantly from 0 to $48 \mathrm{~h}$, while the nuclear levels of NF- $\mathrm{kB} / \mathrm{p} 50$ and NF- $\mathrm{kB} / \mathrm{p} 65$ increased. No significant change in the levels of p53 was observed. Equal loading was confirmed by stripping the blot and reprobing for $\beta$-actin. Significant changes were determined based on three independent experiments.

${ }^{*} \mathrm{p}<0.05$ and ${ }^{* *} \mathrm{p}<0.01$ compared with control $(0 \mathrm{~h}$ of treatment $)$. 


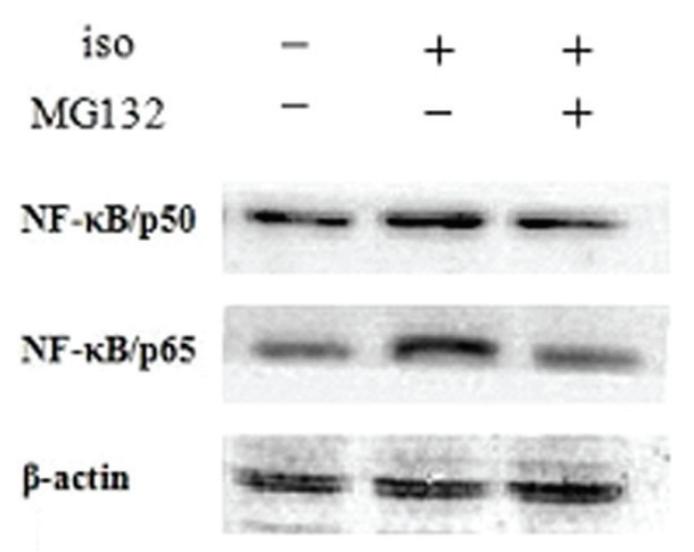

Figure 5. Growth curves of Eca-109 cells pretreated with the NF-kB inhibitor MG132 and then exposed to isorhamnetin. Cells were treated for $90 \mathrm{~min}$ with MG132 $(2 \mu \mathrm{M})$ or $0.1 \%$ DMSO vehicle, these additives were washed out with several changes of medium, and then the cells were treated for 48 h with $130 \mu \mathrm{M}$ isorhamnetin. Pretreatment with MG132 led to significantly less proliferation than treatment with isorhamnetin alone.

Isorhamnetin treatment downregulates the expression of Id- 1 but fails to alter the levels of $\mathrm{p} 53$ protein. Isorhamnetin decreased Id-1 expression in isorhamnetin treated Eca-109 cells. Forty-eight-hour exposure resulted in two thirds less protein level of Id-1, compared with that of Eca-109 cells from the time point $0 \mathrm{~h}$ (Fig. $4 \mathrm{~B}$, Table 4). Nevertheless, this drug did not cause any significant change in levels of p 53 (Fig. 4B, Table 4).

Activation of NF- $\mathrm{kB}$ is essential for proliferation of Eca109 cells during early exposure to isorhamnetin. To confirm the role of NF- $\kappa$ B in Eca-109 cell proliferation, cells were exposed to isorhamnetin after pretreatment with the NF- $\mathrm{kB}$ inhibitor MG132. The inhibitory effect of MG132 was confirmed by Western blot (Fig. 5, Table 5). Under these conditions, no
Growth cultures of Eca-109 cells

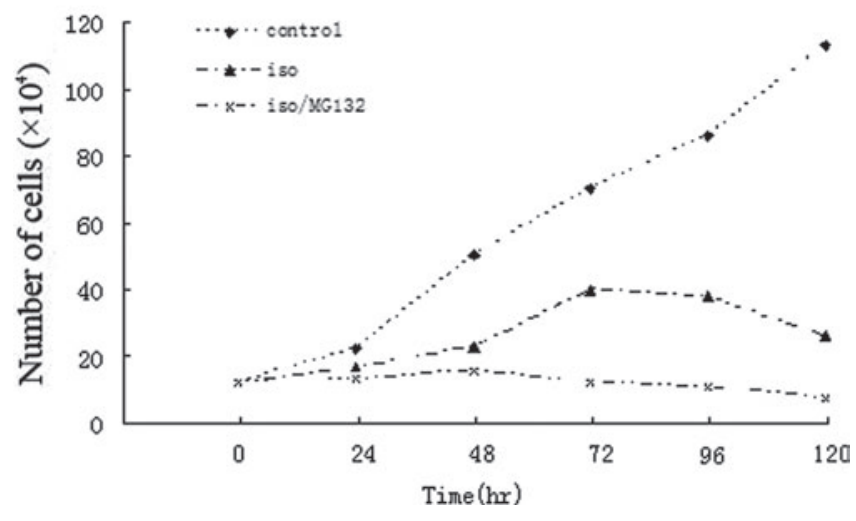

Figure 6. Inhibition by MG132 of isorhamnetin-induced activation of NF-кB. Eca-109 cells were pretreated with MG132 or DMSO vehicle and then treated with isorhamnetin as described in Fig. 5. Nuclear levels of $\mathrm{NF}-\kappa \mathrm{B} / \mathrm{p} 50$ and NF- $\mathrm{\kappa B} / \mathrm{p} 65$ were significantly lower in cells pretreated with MG132 than in those treated with isorhamnetin alone. Results shown are from three independent experiments.

${ }^{* *} \mathbf{p}<0.01$ compared with control cells (no pretreatment)

significant proliferation of cells was observed at any time during exposure to isorhamnetin (Fig. 6). In fact, the number of viable cells was significantly lower in the cells pretreated with MG132 than that in the cells exposed only to isorhamnetin at all time points examined (Fig. 5). These results, together with the increased in COX-2 expression, indicate that the cellular stress response partially inhibited the antiproliferative effects of isorhamnetin during early exposure.

Exposure of Eca-109 cells to isorhamnetin induces changes in the expressions of the apoptotic proteins Bcl2, Bax, and Mcl-1. Expressions of Bcl-2 and Mcl-1 shared the same pattern. Their expressions increased significantly

Table 4. Densitometric analysis of NF- $\mathrm{kB} / \mathrm{p} 50, \mathrm{NF}-\mathrm{\kappa B} / \mathrm{p} 65$, Id-1 and p53 following isorhamnetin

\begin{tabular}{|c|c|c|c|c|c|}
\hline \multirow{2}{*}{$\begin{array}{l}\text { Time } \\
\text { (hr) }\end{array}$} & \multirow{2}{*}{$\mathrm{N}$} & \multicolumn{4}{|c|}{ Relative Optical Density } \\
\hline & & $\mathrm{NF}-\kappa \mathrm{B} / \mathrm{p} 50$ & NF- $\kappa \mathrm{B} / \mathrm{p} 65$ & Id-1 & P53 \\
\hline 0 & 3 & 0 & $996.11 \pm 145.48$ & $7490.65 \pm 151.99$ & $4174.37 \pm 119.79$ \\
\hline 48 & 3 & $2272.86 \pm 104.36^{\star *}$ & $5633.82 \pm 191.77^{\star *}$ & $2503.72 \pm 119.79^{* *}$ & $3868.16 \pm 130.24$ \\
\hline
\end{tabular}

${ }^{*} \mathrm{P}<0.05$ vs. control group ${ }^{* *} \mathrm{P}<0.01$ vs. control group

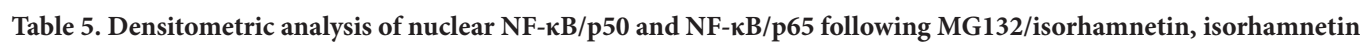

\begin{tabular}{lccc}
\hline \multirow{2}{*}{$\begin{array}{l}\text { Time } \\
\text { (hr) }\end{array}$} & $\mathrm{N}$ & $\mathrm{NF}-\kappa \mathrm{B} / \mathrm{p} 50$ & Relative Optical Density \\
\cline { 3 - 4 } & & $6324.00 \pm 200.50$ & $\mathrm{NF}-\kappa \mathrm{B} / \mathrm{p} 65$ \\
\hline Control & 3 & $11239.00 \pm 526.00^{* *}$ & $4086.00 \pm 184.50$ \\
Iso & 3 & $5464.00 \pm 109.60$ & $9660.00 \pm 369.70^{* *}$ \\
Iso/MG132 & 3 & & $4539.00 \pm 234.20$ \\
\hline${ }^{*} \mathrm{P}<0.05$ vs. control group & $* * \mathrm{P}<0.01$ vs. control group &
\end{tabular}




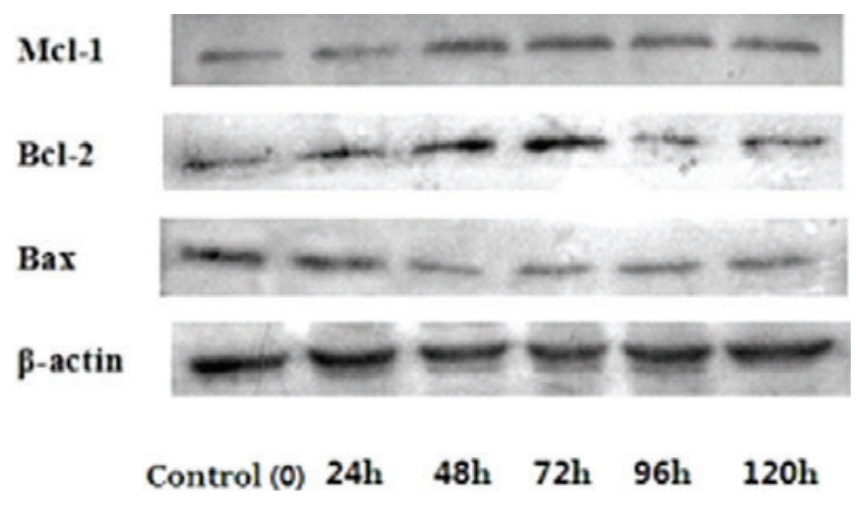

Figure 7. Effect of isorhamnetin on the expression of Mcl-1, Bcl-2 and Bax in Eca-109 cells. Cells were treated with $130 \mu \mathrm{M}$ isorhamnetin for $24,48,72,96$ or $120 \mathrm{~h}$ and whole-cell extracts were analyzed by Western blot. The level of Mcl-1 gradually increased from 0 to $48 \mathrm{~h}$ of exposure to isorhamnetin. The level of Bcl-2 increased sharply, peaking at $72 \mathrm{~h}$ of exposure. On the contrary, the level of Bax decreased from the beginning of exposure, such that nearly no Bax was detected by $48 \mathrm{~h}$. Results are from three independent experiments.

${ }^{*} \mathbf{p}<0.05$ and ${ }^{* *} \mathrm{p}<0.01$ compared with control ( $0 \mathrm{~h}$ of treatment).

immediately after exposure to isorhamnetin, peaked at the point of $72 \mathrm{~h}$, and then gradually decreased during the last $48 \mathrm{~h}$ (Fig. 7, Table 6). In contrast, the expression of Bax decreased for $48 \mathrm{~h}$ and then increased for another $72 \mathrm{~h}$ (Fig. 7, Table 6).

\section{Discussion}

Isorhamnetin has been shown to have antioxidant and antiproliferative activities in a variety of cancer cell lines. In previous work, we found that this compound could inhibit the growth of ESCC Eca-109 cells and induced apoptosis, but only after longer exposure. In the present report, we provide evidence that these effects are delayed because the compound initially induces a cell stress response involving NF- $\kappa \mathrm{B}$ activation and COX-2 upregulation, which allows the cells to grow slowly for at least $72 \mathrm{~h}$. These results indicate that the cellular stress response will need to be taken into account when developing isorhamnetin as an anticancer drug.
Aberrant expression of COX-2 has been reported in several types of cancer [30,31,32,33,34], and constitutive COX-2 activity may stimulate cellular proliferation of ESCC cells [34]. Jones et al reported that isorhamnetin was a potent inhibitor of COX-2 activity in the human colorectal cancer cell line HCA-7. While the present study showed that isorhamnetin did downregulate COX-2 expression during longer exposure, expression was upregulated during the first $48 \mathrm{~h}$. During this

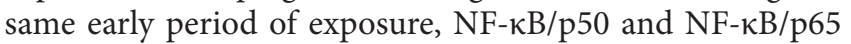
accumulated in the nucleus. These results suggest that short exposure to isorhamnetin induces a cell stress response involving COX-2 upregulation and NF- $\kappa$ B activation in Eca-109 cells. These findings led us to examine the isorhamnetin-induced stress response in greater detail.

The transcription factor NF- $\kappa \mathrm{B}$ plays a key role in the transcriptional regulation of adhesion molecules, enzymes and cytokines involved in chronic inflammatory diseases [35], and in transcriptional regulation in various cancer cell models, including esophageal carcinoma[36]. Activation of $\mathrm{NF}-\kappa \mathrm{B}$ is associated with numerous signalling events, including upregulation of COX-2 expression[37]. NF- $\mathrm{B}$ normally exists in the cytoplasm as inactive complexes with inhibitory proteins of the I $\mathrm{B}$ family. In the present study, we found that isorhamnetin induced significant degradation of $I \kappa B a$ and nuclear accumulation of NF- $\kappa \mathrm{B} / \mathrm{p} 50$ and NF- $\mathrm{kB} / \mathrm{p} 65$ within $48 \mathrm{~h}$. Consistent with a previous report that the NF- $\kappa \mathrm{B}$ inhibitor MG132 blocks the disappearance of IкBa, we found that it blocked the isorhamnetin-induced degradation of $I \kappa B a$ under our conditions. We also found that it downregulated the expression of NF- $\mathrm{kB} / \mathrm{p} 50$ and NF- $\mathrm{BB} / \mathrm{p} 65$ in isorhamnetintreated cells. Together with our previous work [7], the present study shows that isorhamnetin activates the NF- $\kappa$ B pathway.

This NF- $\kappa \mathrm{B}$ activation may be part of a pro-survival response during isorhamnetin-induced endosplasmic reticular stress. This pathway may contribute to a premalignant phenotype not only by promoting cell proliferation and survival, but also by upregulating genes that control cell adhesion and angiogenesis[38] and that express proteins involved in antiapoptosis (Bcl-2, Bcl-xL) and proliferation (cyclin D1, c-Myc) [39].

In vitro studies support the idea that COX-2 over-expression inhibits apoptosis and promotes tumor angiogenesis

Table 6. Densitometric analysis of Mcl-1, Bcl-2 and Bax following isorhamnetin

\begin{tabular}{|c|c|c|c|c|}
\hline \multirow{2}{*}{$\begin{array}{l}\text { Time } \\
\text { (hr) }\end{array}$} & \multirow{2}{*}{$\mathrm{N}$} & \multicolumn{3}{|c|}{ Relative Optical Density } \\
\hline & & Mcl-1 & Bcl-2 & $\operatorname{Bax}$ \\
\hline 0 & 3 & $2669.67 \pm 174.95$ & $2962.33 \pm 91.52$ & $7259.22 \pm 139.67$ \\
\hline 24 & 3 & $2598.00 \pm 126.89$ & $3772.33 \pm 191.82^{\star *}$ & $6048.00 \pm 303.48^{* *}$ \\
\hline 48 & 3 & $6548.00 \pm 145.49^{* *}$ & $5276.00 \pm 252.48^{\star *}$ & $2303.33 \pm 272.09^{* *}$ \\
\hline 72 & 3 & $6413.67 \pm 124.54^{* *}$ & $6247.33 \pm 178.30^{\star *}$ & $2752.33 \pm 209.00^{* *}$ \\
\hline 96 & 3 & $4503.00 \pm 80.47^{\star \star}$ & $2017.67 \pm 111.43^{\star *}$ & $3481.33 \pm 145.84^{\star *}$ \\
\hline 120 & 3 & $4110.00 \pm 50.86^{\star *}$ & $2340.67 \pm 68.13^{*}$ & $4018.00 \pm 189.41^{\star *}$ \\
\hline
\end{tabular}

${ }^{\star} \mathrm{P}<0.05$ vs. control group $\quad{ }^{* *} \mathrm{P}<0.01$ vs. control group 
$[40,41,42]$. Indeed, several studies support a role of COX-2 overexpression in tumor growth promotion $[41,43]$. Previous work showed isorhamnetin to be a potent inhibitor of COX-2 activity in the human colorectal cancer cell line HCA-7[29]. However, we observed in the present study that the level of COX-2 was initially upregulated and peaked at $48 \mathrm{~h}$. These data suggest that COX-2 may participate in the isorhamnetininduced stress response by preventing apoptosis.

Akt kinase is activated when it is phosphorylated on threonine 308 or serine 473 by phosphoinositide 3-kinase (PI-3K). This phospho-Akt has been proposed to activate NF- $\kappa$ B by phosphorylating IKK $[13,44]$. Some reports have also suggested that Akt directly regulates the expression of COX-2 [45]. However, our results show that isorhamnetin-induced NF- $\kappa \mathrm{B}$ activation and upregulation of COX-2 expression in Eca-109 cells did not involve Akt phosphorylation. These findings suggest that NF- $\kappa \mathrm{B}$ activation does not necessarily involve Akt phosphorylation, especially during exposure to isorhamnetin.

Recent reports have associated upregulation of Id-1 protein with cell proliferation in several human cell lines [46,47]. In prostate cancer cells, NF- $\kappa \mathrm{B}$ activation may regulate the growth-promoting effect of Id-1 in order to protect against apoptosis [12]. In contrast to these reports, we found that under our experimental conditions, the level of Id-1 protein decreased during the first $48 \mathrm{~h}$ of exposure to isorhamnetin, while the expression of NF- $\kappa \mathrm{B}$ increased. One possible explanation for these discrepant results is that isorhamnetin targets the gene encoding Id-1 and represses its transcription. Another possible explanation is that in Eca-109 cells, isorhamnetininduced NF- $\kappa \mathrm{B}$ activation does not involve Id- 1 .

COXs catalyze the oxidative metabolism of arachidonic acid into prostaglandin $\mathrm{H} 2$, which is the precursor of other prostaglandins including prostaglandin G2 (PEG2) $[48,49]$. PEG2 has been reported to inhibit Fas-induced apoptosis and markedly increase expression of Mcl-1 in KMBC cholangiocarcinoma cells [50]. Mcl-1 is a member of the Bcl-2 family and a potent inhibitor of the mitochondrial pathway of apoptosis. Thus, one way in which COX-2 inhibits apoptosis is by upregulating Mcl-1. Consistent with these previous studies, we found that the level of Mcl-1 increased during early exposure to isorhamnetin. In addition, the ratio of Bax to Bcl-2 proteins noticeably decreased from 0 to $48 \mathrm{~h}$, and a decrease in this ratio is considered an indicator of apoptosis inhibition in mammalian cells.

The present study does not explain how isorhamnetin upregulates COX-2 expression. While previous work indicates that such upregulation occurs via downregulation of p53 or activation of the Akt signalling pathway [26,27,28], we did not observe changes in the levels of either p53 or phosphorylated Akt under our experimental conditions. Future studies should examine whether the COX-2 upregulation in this cell line occurs by a novel or known signaling pathway.

In conclusion, we provide here evidence that isorhamnetin causes a positive stress response in Eca-109 cells. NF- $\kappa \mathrm{B}$ acti- vation and upregulation of COX-2 are involved in this stress response during the first $72 \mathrm{~h}$ of exposure. The activation of the $\mathrm{I} \kappa \mathrm{B} \alpha / \mathrm{NF}-\kappa \mathrm{B} / \mathrm{COX}-2$ signaling pathway and the reduction in $\mathrm{Bax} / \mathrm{Bcl}-2$ ratio promote cell survival and proliferation during this period. Further studies are needed to determine whether additional molecules help to modulate the antiproliferative and apoptotic effects of isorhamnetin. In particular, although previous studies have shown that downregulation of p53 induces COX-2 overexpression, we did not see evidence that p53 is involved in the cell stress response under our experimental conditions. Further studies are needed to clarify the molecular events behind this stress response, which may help us understand the cellular processes that weaken or negate the anticancer properties of isorhamnetin.

Acknowledgments: This research was funded by the National Basic Research Program of China (973 Program), No. 2011CB711000 and Science and Technology Project of Sichuan, China, (2011SZ0116).

\section{References}

[1] PISANI P, BRAY F, PARKIN DM Estimates of the world-wide prevalence of cancer for 25 sites in the adult population. Int J Cancer 2002; 97: 72-81. http: //dx.doi.org/10.1002/ijc.1571

[2] SOUZA RF Molecular and biologic basis of upper gastrointestinal malignancy-esophageal carcinoma. Surg Oncol Clin N Am 2002; 11: 257-272. http: //dx.doi.org/10.1016/S10553207(02)00003-0

[3] STONER GD, GUPTA A Etiology and chemoprevention of esophageal squamous cell carcinoma. Carcinogenesis 2001; 22: 1737-1746. http: //dx.doi.org/10.1093/carcin/22.11.1737

[4] ECHEVERRY C, BLASINA F, ARREDONDO F, FERREIRA M, ABIN-CARRIQUIRY JA et al. Cytoprotection by neutral fraction of tannat red wine against oxidative stress-induced cell death. J Agric Food Chem 2004; 52: 7395-7399. http: //dx.doi.org/10.1021/jf040053q

[5] IBARRA M, PEREZ-VIZCAINO F, COGOLLUDO A, DUARTE J, ZARAGOZA-ARNAEZ F et al.Cardiovascular effects of isorhamnetin and quercetin in isolated rat and porcine vascular smooth muscle and isolated rat atria. Planta Med 2002; 68: 307-310. http: //dx.doi.org/10.1055/s-2002-26752

[6] TENG BS, LU YH, WANG ZT, TAO XY, WEI DZ In vitro anti-tumor activity of isorhamnetin isolated from Hippophae rhamnoides L. against BEL-7402 cells. Pharmacol Res 2006; 54: 186-194. http: //dx.doi.org/10.1016/j.phrs.2006.04.007

[7] MA G, YANG CL, QU Y, WEI HY, ZHANG TT et al.The flavonoid component isorhamnetin in vitro inhibits and induces apoptosis in Eca-109 cells. Chem Biol Interact 2007; 167: 153-160. http: //dx.doi.org/10.1016/j.cbi.2007.02.006

[8] COURTOIS G, GILMORE TD Mutations in the NF-kappaB signaling pathway: implications for human disease. Oncogene 2006; 25: 6831-6843. http: //dx.doi.org/10.1038/ sj.onc. 1209939

[9] HAYDEN MS, GHOSH S Shared principles in NF- $\mathrm{B}$ signaling. Cell 2008; 132: 344-362. http://dx.doi.org/10.1016/ j.cell.2008.01.020 
[10] NEERGHEEN VS, BAHORUN T, TAYLOR EW, JEN LS, ARUOMA OI Targeting specific cell signaling transduction pathways by dietary and medicinal phytochemicals in cancer chemoprevention. Toxicol 2010; 278: 229-241. http: //dx.doi. org/10.1016/j.tox.2009.10.010

[11] XU Z, LIN S, WU W, TAN H, WANG Z et al.Ghrelin prevents doxorubicin-induced cardiotoxicity through TNF-alpha/NFkappaB pathways and mitochondrial protective mechanisms. Toxicol 2008; 247: 133-138. http: //dx.doi.org/10.1016/ j.tox.2008.02.018

[12] LING MT, WANG X, OUYANG XS, XU K, TSAO SW et al.Id-1 expression promotes cell survival through activation of NF-kappaB signalling pathway in prostate cancer cells. Oncogene 2003; 22: 4498-4508. http: //dx.doi.org/10.1038/ si.onc. 1206693

[13] KANE LP, SHAPIRO VS, STOKOE D, WEISS A Induction of NF-kappaB by the Akt/PKB kinase. Curr Biol 1999; 9: 601-604. http: //dx.doi.org/10.1016/S0960-9822(99)80265$\underline{6}$

[14] SMITH WL, GARAVITO RM, DEWITT DL Prostaglandin endoperoxide $\mathrm{H}$ synthases (cyclooxygenases)-1 and -2. J Biol Chem 1996; 271: 33157-33160. http: //dx.doi.org/10.1074/ ibc.271.17.9906

[15] SMITH WL, DEWITT DL Biochemistry of prostaglandin endoperoxide $\mathrm{H}$ synthase- 1 and synthase- 2 and their differential susceptibility to nonsteroidal anti-inflammatory drugs. Semin Nephrol 1995; 15: 179-194.

[16] HEMPEL SL, MONICK MM, HUNNINGHAKE GW Lipopolysaccharide induces prostaglandin $\mathrm{H}$ synthase-2 protein and mRNA in human alveolar macrophages and blood monocytes. J Clin Invest 1994; 93: 391-396. http: //dx.doi. org/10.1172/JCI116971

[17] COK SJ, MORRISON AR The 3'-untranslated region of murine cyclooxygenase- 2 contains multiple regulatory elements that alter message stability and translational efficiency. J Biol Chem 2001; 276: 23179-23185. http://dx.doi.org/10.1074/jbc. M008461200

[18] Li F, Liu Y, Chen H, Liao D, Shen Y et al.EGFR and COX-2 protein expression in non-small cell lung cancer and the correlation with clinical features. J Exp Clin Cancer Res 2011; 30(1): 32. http: //dx.doi.org/10.1186/1756-9966-30-32

[19] EL-SAYED M, TAHA MM Immunohistochemical expression of cycloxygenase- 2 in astrocytoma: correlation with angiogenesis, tumor progression and survival. Turk Neurosurg 2011; 21: 27-35.

[20] CHANDRASEKHARAN NV, DAI H, ROOS KL, EVANSON NK, TOMSIK J et al.COX-3, a cyclooxygenase-1 variant inhibited by acetaminophen and other analgesic/antipyretic drugs: cloning, structure, and expression. Proc. Natl. Acad. Sci. USA 2002; 99: 13926-13931. http: //dx.doi.org/10.1073/ pnas. 162468699

[21] DANNENBERG AJ, ALTORKI NK, BOYLE JO, DANG C, HOWE LR et al. Cyclo-oxygenase 2: a pharmacological target for the prevention of cancer. Lancet Oncol 2001; 2: 544-551. http://dx.doi.org/10.1016/S1470-2045(01)00488-0

[22] CHEN CC, SUN YT, CHEN JJ, CHANG YJ Tumor necrosis factor-induced cyclooxygenase-2 expression via sequential activation of ceramide-dependent mitogen-activated protein kinases, and IB kinase 1/2 in human alveolar epithelial cells. Mol Pharmacol 2001; 59: 493-500.

[23] DEMPKE W, RIE C, GROTHEY A, SCHMOLL HJ Cyclooxygenase-2: a novel target for cancer chemotherapy. J Cancer Res Clin Oncol 2001; 127: 411-417. http: //dx.doi. org/10.1007/s004320000225

[24] PEPPELENBOSCH MP, TERTOOLEN LG, HAGE WJ, DE LAAT SW Epidermal growth factor-induced actin remodeling is regulated by 5 -lipoxygenase and cyclooxygenase products. Cell 1993; 74: 565-575. http: //dx.doi.org/10.1016/00928674(93)80057-L

[25] ZHANG F, SUBBARAMAIAH K, ALTORKI N, DANNENBERG AJ Dihydroxy bile acids activate the transcription of cyclooxygenase-2. J Biol Chem 1998; 273: 2424-2428. http: //dx.doi.org/10.1074/jbc.273.4.2424

[26] SUBBARAMAIAH K, ALTORKI N, CHUNG WJ, MESTRE JR, SAMPAT A et al. Inhibition of cyclooxygenase-2 gene expression by p53. J Biol Chem 1999; 274: 10911-10915. http: //dx.doi.org/10.1074/jbc.274.16.10911

[27] SHAO J, SHENG H, INOUE H, MORROW JD, DUBOIS RN Regulation of constitutive cyclooxygenase-2 expression in colon carcinoma cells. J Biol Chem 2000; 275: 33951-33956. http: //dx.doi.org/10.1074/jbc.M002324200

[28] TANG Q, GONZALES M, INOUE H, BOWDEN GT Roles of Akt and glycogen synthase kinase $3 \beta$ in the ultraviolet $B$ induction of cyclooxygenase-2 transcription in human keratinocytes. Cancer Res 2001; 61: 4329-4332.

[29] JONES DJ, LAMB JH, VERSCHOYLE RD, HOWELLS LM, BUTTERWORTH $\mathrm{M}$ et al. Characterisation of metabolites of the putative cancer chemopreventive agent quercetin and their effect on cyclooxygenase activity. Br J Cancer 2004; 91 : 1213-1219.

[30] HIDA T, YATABE Y, ACHIWA H, MURAMATSU H, KOZAKI K et al.Increased expression of cyclooxygenase 2 occurs frequently in human lung cancers, specifically in adenocarcinomas. Cancer Res1998; 58: 3761-3764.

[31] RISTIMAKI A, HONKANEN N, JANKALA H, SIPPONEN P, HARKONEN M Expression of cyclooxygenase-2 in human gastric carcinoma. Cancer Res 1997; 57: 1276-1280.

[32] SANO H, KAWAHITO Y, WILDER RL, HASHIRAMOTO A, MUKAI S et al.Expression of cyclooxygenase-1 and -2 in human colorectal cancer. Cancer Res 1995; 55: 3785-3789.

[33] ZIMMERMANN KC, SARBIA M, WEBER AA, BORCHARD F, GABBERT HE et al.Cyclooxygenase-2 expression in human esophageal carcinoma. Cancer Res 1999; 59: 198-204.

[34] ZHI H, WANG L, ZHANG J, ZHOU C, DING F et al.Significance of COX-2 expression in human esophageal squamous cell carcinoma. Carcinogenesis 2006; 27: 1214-1221. http: //dx.doi.org/10.1093/carcin/bgi304

[35] BARNES PJ, KARIN M Nuclear factor-kappaB: a pivotal transcription factor in chronic inflammatory diseases. $\mathrm{N}$ Engl J Med 1997; 336: 1066-1071. http: //dx.doi.org/10.1056/ NEJM199704103361506

[36] THIEL A, HEINONEN M, RINTAHAKA J, HALLIKAINEN T, HEMMES A et al. Expression of cyclooxygenase- 2 is regulated by glycogen synthase kinase- $3 \beta$ in gastric cancer cells. J 
Biol Chem 2006; 281: 4564-4569. http: //dx.doi.org/10.1074/ jbc.M512722200

[37] RODRIGUES S, BRUYNEEL E, RODRIGUE CM, SHAHIN E, GESPACH C Cyclooxygenase 2 and carcinogenesis. Bull Cancer 2004; 91: S61-76. [In French]

[38] BALDWIN AS Control of oncogenesis and cancer therapy resistance by the transcription factor NF-kappaB. J Clin Invest 2001; 107: 241-246. http: //dx.doi.org/10.1172/JCI11991

[39] PANDEY MK, SUNG B, AHN KS, KUNNUMAKKARA AB, CHATURVEDI MM et al. Gambogic acid, a novel ligand for transferrin receptor, potentiates TNF-induced apoptosis through modulation of the nuclear factor-kappaB signaling pathway. Blood 2007; 110: 3517-3525. http: //dx.doi. org/10.1182/blood-2007-03-079616

[40] DUBOIS RN, ABRAMSON SB, CROFFORD L, GUPTA RA, SIMON LS et al. Cyclooxygenase in biology and disease. FASEB J 1998; 12: 1063-1073.

[41] LIU CH, CHANG SH, NARKO K, TRIFAN OC, WU MT et al. Overexpression of cyclooxygenase- 2 is sufficient to induce tumorigenesis in transgenic mice. J Biol Chem 2001; 276: 18563-18569. http: //dx.doi.org/10.1074/jbc.M010787200

[42] TSUJII M, KAWANO S, TSUJI S, SAWAOKA H, HORI M et al. Cyclooxygenase regulates angiogenesis induced by colon cancer cells. Cell 1998; 93: 705-716. http: //dx.doi. org/10.1016/S0092-8674(00)81433-6

[43] MULLER-DECKER K, NEUFANG G, BERGER I, NEUMANN M, MARKS F et al.Transgenic cyclooxygenase-2 overexpression sensitizes mouse skin for carcinogenesis. Proc Natl Acad Sci USA 2002; 99: 12483-12488. http: //dx.doi. org/10.1073/pnas.192323799

[44] WANG Y, CHANG J, LI YC, LI YS, SHYY JY et al.Shear stress and VEGF activate IKK via the Flk-1/Cbl/Akt signaling pathway. Am J Physiol Heart Circ Physiol 2004; 286: 685-692. http: //dx.doi.org/10.1152/ajpheart.00237.2003

[45] ST-GERMAIN ME, GAGNON V, MATHIEU I, PARENT S, ASSELIN E et al. Akt regulates COX-2 mRNA and protein expression in mutated-PTEN human endometrial cancer cells. Int J Oncol 2004; 24: 1311-1324.

[46] HARA E, YAMAGUCHI T, NOJIMA H, IDE T, CAMPISI J et al. Id-related genes encoding helix-loop-helix proteins are required for G1 progression and are repressed in senescent human fibroblasts. J Biol Chem 1994; 269: 2139-2145.

[47] HARA E, UZMAN JA, DIMRI GP, NEHLIN JO, TESTORI A et al. The helix-loop-helix protein Id-1 and a retinoblastoma protein binding mutant of SV40 T antigen synergize to reactivate DNA synthesis in senescent human fibroblasts. Dev Genet 1996; 18: 161-172. http: //dx.doi.org/10.1002/(SICI)15206408(1996)18: 2<161: : AID-DVG9>3.0.CO; 2-7

[48] HO CC, LING YC, CHANG LW, TSAI HT, TSAI MH et al.17-beta estradiol and hydroxyestradiols interact via the NFKappaB pathway to elevate cyclooxygenase 2 expression and prostaglandin E2 secretion in human bronchial epithelial cells. Toxicol Sci 2008; 104: 294-302. http: //dx.doi.org/10.1093/tox$\underline{\text { sci/kfn096 }}$

[49] BREN-MATTISON Y, MEYER AM, VANPUTTEN V, LI $\mathrm{H}, \mathrm{KUHN} \mathrm{K}$ et al. Antitumorigenic effects of peroxisome proliferator-activated receptor in non-small-cell lung cancer cells are mediated by suppression of cyclooxygenase- 2 via inhibition of nuclear factor. Mol Pharmacol 2008; 73: 709-717. http: //dx.doi.org/10.1124/mol.107.042002

[50] NZEAKO UC, GUICCIARDI ME, YOON JH, BRONK SF, GORES GJ COX-2 inhibits Fas-mediated apoptosis in cholangiocarcinoma cells. Hepatol 2002; 35: 552-559. http: //dx.doi. org/10.1053/jhep.2002.31774 